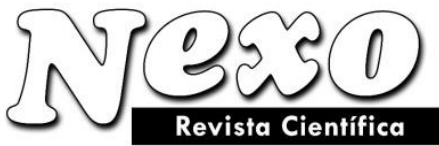

ISSN-E 1995-9516

Universidad Nacional de Ingeniería COPYRIGHT @ (UNI). TODOS LOS DERECHOS RESERVADOS

http://revistas.uni.edu.ni/index.php/Nexo

https://doi.org/10.5377/nexo.v34i04.12648

Vol. 34, No. 04, pp. 1200-1214/Septiembre 2021

(c) (i) $(-)$

\title{
Petrology of lamprophyric in northern Jirandeh, Iran
}

\section{Petrología de lamprofírica en el norte de Jirandeh, Irán}

\author{
Abdolreza Soleimani ${ }^{1}$, Shahrooz Haghnazar ${ }^{1 *}$, Mansour Vosoughi Abedini ${ }^{2}$, Saeed Hakimi Asiaber ${ }^{1}$ \\ ${ }^{1}$ Depatment of Geology, Islamic Azad University, Lahijan Branch, Lahijan, Iran. \\ ${ }^{2}$ Associate Professor, Department of Geology, Faculty of Earth Sciences, Shahid Beheshti \\ University, Tehran, Iran. \\ * $\underline{\text { sh_haghnazar@yahoo.com }}$
}

(recibido/received: 28-mayo-2021; aceptado/accepted: 18-agosto-2021)

\begin{abstract}
This study was performed on the outcrops of lamprophyric lavas found in the north of Jirandeh and east of Lushan in the mountain of Alborz (north of Iran). These lavas has been placed discordantly on the middle Eocene lime..Petrographic observation indicates olivine phenocrysts, green-core alkaline clinopyroxenes, nepheline, abundant biotite, and apatites with flakes. and in the matrix it also contains biotite, olivine, clinopyroxene and plagioclase.The presence of carbonates, plagioclase and xenocrystals with rounded margins asserts the contamination with continental crust Petrologically, these rocks classify as alkaline lamprophyres of comptonite variety. These rocks can be subsumed under alkaline sodic categories at $\mathrm{K} 2 \mathrm{O} / \mathrm{Na} 2 \mathrm{O}<1$ ratio. The rare elements patterns in the rocks, normalized with the primitive mantle, causing partial negative $\mathrm{Nb}$ anomalies and showing no blades at the surface. It, therefore, can be indicative of the evidence for an intraplate magmatism with the different degree in the crustal contamination. Geochemistry states the first cause of asthenospheric flow can be occurred at $\mathrm{La} / \mathrm{Nb}<1$ and $\mathrm{La} / \mathrm{Ta} 13$ ratios, and the presence of garnet can be assumed at $1 / 8<(\mathrm{Tb} / \mathrm{Yb}) \mathrm{N}$ ratio in the rocks origin area. In tectonic discrimination diagrams, these rocks fall in the range of intra-continental rift zones. Geochemical analyses indicate that these lamprophyres originate from partial (1\%) melting of an OIB-like asthenospheric mantle source of lherzolite garnet nature.
\end{abstract}

Key words: Jirandeh, intra-continental rift, alkaline lamprophyre, OIB source.

\section{RESUMEN}

Este estudio se realizó en las formaciones de lavas lamprofíricas que se encuentran en el norte de Jirandeh y al este de Lushan en la montaña de Alborz (norte de Irán). Estas lavas se han colocado discordantemente en la cal del Eoceno medio. La observación petrográfica indica fenocristales de olivino, clinopiroxenos alcalinos de núcleo verde, nefelina, abundante biotita y apatitas con escamas. y en la matriz también contiene biotita, olivino, clinopiroxeno y plagioclasa. La presencia de carbonatos, plagioclasa y xencristales con márgenes redondeados afirma la contaminación con corteza continental. Petrológicamente, estas rocas se clasifican como lamprofiros alcalinos de la variedad comptonita. Categorías sódicas alcalinas en relación $\mathrm{K} 2 \mathrm{O} / \mathrm{Na} 2 \mathrm{O}<1$. Los patrones de elementos raros en las rocas, 
normalizados con el manto primitivo, causan anomalías de Nb negativas parciales y no muestran láminas en la superficie. Por lo tanto, puede ser indicativo de la evidencia de un magmatismo intraplaca con el diferente grado de contaminación de la corteza. La geoquímica establece que la primera causa del flujo astenosférico puede ocurrir en las relaciones $\mathrm{La} / \mathrm{Nb}<1$ y La / Ta 13, y la presencia de granate se puede suponer en una relación 1/8<(Tb / Yb) $\mathrm{N}$ en el área de origen de las rocas. En los diagramas de discriminación tectónica, estas rocas caen en el rango de zonas de rift intracontinental. Los análisis geoquímicos indican que estos lamprofiros se originan a partir de la fusión parcial (1\%) de una fuente de manto astenosférico similar a OIB de naturaleza granate lherzolita.

Palabras clave: Jirandeh, rift intracontinental, lamprofira alcalina, fuente de OIB

\section{INTRODUCTION}

Different tectonic environments for instance island arcs, active continental margins, rifts, and cratons impact on the formation of the rocks that almost overlap with other igneous rocks. The different tectonically environments of Iran, such as Alborz, Centeral Iran, and Azerbaijan were involved in the formation of lamprophyres from Paleozoic ear until Quaternary period.

The larger part of them are volcanic rather than semi-volcanic. In Centeral Iran, for instance, there are some lamprophyres in the northern east of Isfahan province that showed Alkaline characteristics, and categorized as camptonites. These lamprophyres were emerged in an intraplate tectonic setting and formed by the melting of garnet peridotite with small degree. On the other hand, some of the other lamprophyres in Chāh-e Palang, located in Central Iran, were created by the melting of rich metasomatic $\mathrm{CO}_{2}$ fluids in amphibole-bearing spinel lerzolite with small degree. They are named as 'Paleolithic subduction'.

Lamprophyre dikes that are found in Shahi Island, located in Azerbaijan, display calc-alkaline characteristics. It is assumed that they were formed in a tectonic environment caused by melting garnet lerzolite $\mathrm{H}_{2} \mathrm{O}-\mathrm{CO}_{2}$ rich fluids.

Fazl-nia and Kolani (2010) discovered the alkaline lamprophyres in the northwest of Iran, Salmas, that formed in the period of quaternary. Their study concluded that the formation was caused by the enriched spinel lherzolite involved in mantle melting after the occurrence of the collision between Arabian Plate and Eurasia, resulted in the contamination with continental crust. Firstly, it should be verified that no reports have been confirmed on the existence of the lamprophyres in Cenozoic volcanoes of Alborz, Northern Iran. 1:100 000 Scale Map of Jirandah reveals no signs of Cenozoic lava based on lamprophyres. Thus, the present study reports and introduces them as the first time ever in the literature. It also focuses on mineralogical and geochemical studies on lamprophyre magmatism, the tectonic settings, and the origins of magmas in Alborz to state the results.

\section{METHODOLOGY}

In a field survey, the researchers collected 50 samples from the study area. After preparing the thin-sections of samples, mineralogical and lithological analyses were performed with a polarizing microscope. For geochemical analysis, 8 samples were sent to the SGS Toronto laboratory, where eight of them were analyzed with the ICP-AES method for main elements and the other eight were analyzed with the ICP-MS method for secondary elements and rare earth 
elements. Samples were sieved through stainless sieve of $75 \mu \mathrm{m}$ aperture to measure the main and rare elements. Then, $0.2 \mathrm{~g}$ of the sample was melted by lithium metaborate and dissolved by dilute nitric acid. Using ICP-AES and ICP-MS methods, the main and the rare values were respectively obtained as well as REE.For isotope analysis, two samples were sent to the Isotope Laboratory of the University of Geneva to determine ${ }^{87} \mathrm{Sr} /{ }^{86} \mathrm{Sr}$ and ${ }^{143} \mathrm{Nd} /{ }^{144} \mathrm{Nd}$ ratios. Igpet software (2007) was used in the analysis of the geochemical results.

\section{GEOLOGY OF THE STUDY AREA}

The area of interest to this study is located north of Jirandeh, southeast of Rasht and east of Rudbar in the Gilan province, Iran, between $36^{\circ} 42^{\prime}$ and $36^{\circ} 47^{\prime}$ northern latitudes and $49^{\circ} 43^{\prime}$ and $49^{\circ} 46^{\prime}$ eastern longitudes (Figure 1). This area is positioned in the central section of the Jirandeh 1:100000 sheet, which encompasses parts of central Alborz that feature rock units from the Paleozoic up to the present (Ghalamghash, 2002; Bazoobandi et al. 2016; Yazdi et al. 2019-a). According to Stoecklin's zoning (in which Alborz Mountains are divided into six formation zones from north to south), the study area is positioned in the southern central Alborz zone. In this zone, pre-Cenozoic shallow sedimentary deposits are covered by very thick volcanic rocks belonging to the Cenozoic era, especially Eocene (Stoecklin, 1974; Baratian et al. 2020; Yazdi and Sharifi Teshnizi 2021;). According to the zoning of Engalence (1986), the study area is located in the central tertiary zone. There are two main theories about tertiary magmatism in Iran: one group of researchers believe that tertiary magmatism has been caused by the neotethys subduction and strong collision of Iran and Saudi Arabia plates (Moein Vaziri, 2008; Poorbehzadi et al. 2019), but a second group attribute them to a series of intra-continental rifts in the tertiary period (Emami, 1981). Studies carried out in the regions adjacent to the area of interest have given contradicting results, as some state that tertiary rocks belong to the subduction regions (BehzadZadeh, 1999, Taki, 2008) while others believe that they belong to intracontinental rift zones (Esmaeili, 2002 and Shafei, 2002).

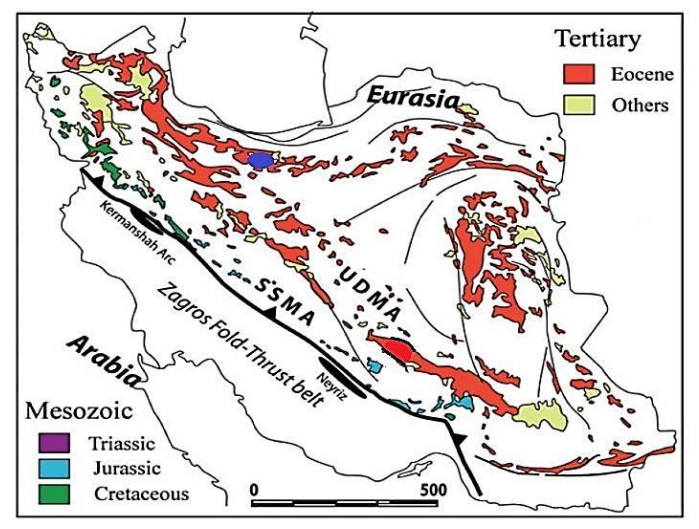

Figure 1. The study area in the structure maps of Iran (Agard et al., 2011).

According to the 1:100,000 map of Jirandeh (Figure 2), the outcrops present in the region -in order of age- are sedimentary deposits of Permian (Dorud formation), shale deposits and sandstones of lower Jurassic (Shemshak formation), conglomerate deposits of Paleocene, calcareous units $\mathrm{E}^{1}$ of Eocene, basalt-andesite unit $\mathrm{E}^{\text {at }}$ of middle Eocene, and intrusions with gabbroid composition, which belong to Oligocene. The calcareous unit $\mathrm{E}^{1}$ encompass a major 
portion of the southern half of the region and contains nummulites belonging to lower to middle Eocene (Ghalamghash, 2002; Yazdi et al. 2019-b). However, our field studies revealed the presence of outcrops of magmas that rest unconformably over unit $\mathrm{E}^{1}$, which also have outcrops in the northern part of the Jirandeh fault. Our examination showed that these magmas have completely different mineralogical and lithological composition than the magmas of unit $\mathrm{E}^{\text {at }}$ (Eocene). Given their discordant position on the lime units of middle Eocene, these rocks can be dated to post Eocene epochs and possibly Miocene to Pliocene.

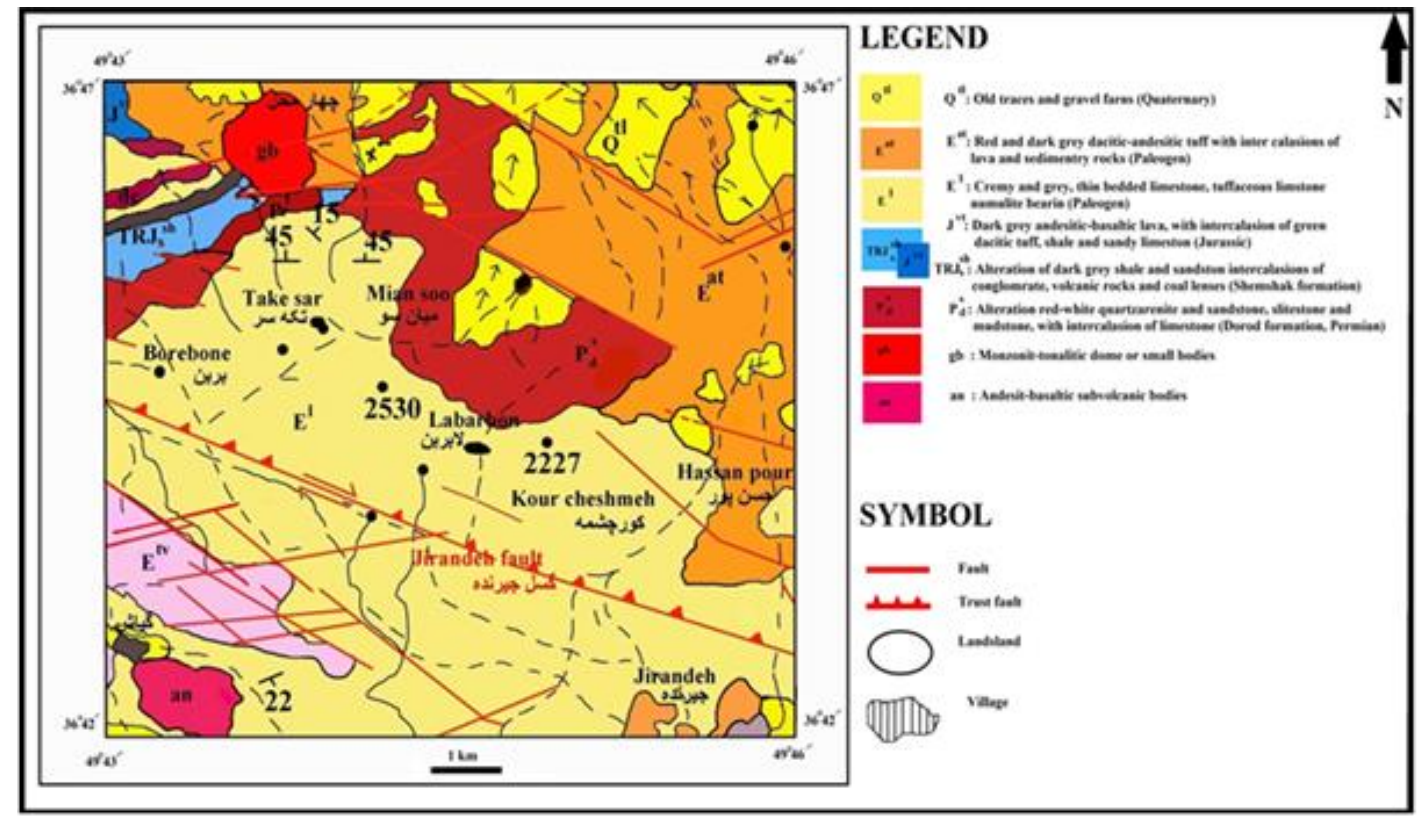

Figure 2: Geological map of northern Jirandeh in the Jirandeh 1:100,000 geological sheet

\subsection{Petrography}

The dominant rock texture of the area is porphyritic with microlitic to medium-grained matrix. In terms of mineral texture, the rocks consist of clinopyroxene, olivine, and biotite, in order of frequency (these minerals can be seen as both phenocryst and matrix). The observed clinopyroxenes are mostly automorphic to semi-automorphic and occasionally multicolored with shades of violet. These clinopyroxenes have a regional structure and sometimes have a green core with violet framing, which reflects the high $\mathrm{Na}$ and $\mathrm{Ti}$ contents of the mineral and its alkaline nature (Figure 3). Mainly, the green-core alkaline clinopyroxenes formation can be observed in continental alkaline basaltic magmatism that are more common in rifts. In some cases, they were reported within a continental plate such as the Eifel (Germany). $\mathrm{Ti}^{+3}$ and $\mathrm{Al}^{+3}$ ratios involve with forming the purple margins which happens as the result of the decreasing pressure during the subtraction of an alkali basaltic magma. It seems that their chemical compound contains titan augite rather than Aegirine Augite. The intensity of purple margins depends on the presence of $\mathrm{Ti}^{+3}$ ratio. These green-core, enriched in Ti titan augites were however reported in the alkaline basaltic provinces of Germany.In some samples, these clinopyroxenes have been altered to brown hornblende (Figure 4)The second most abundant mineral in these rocks is olivine, which can be observed in both coarse and fine crystalline forms(Figure 5). Nepheline crystals can be observed as phenocrysts and micro phenocryst in Glomeroporphyritic textures (Figure 6). The third most 
frequent mineral in the examined rocks is biotite, which can be found both as microphenocryst and in the matrix. The observed biotites are mostly automorphic and do not show any sign of alteration from other minerals and thus seem to be completely primary (Figure 4).

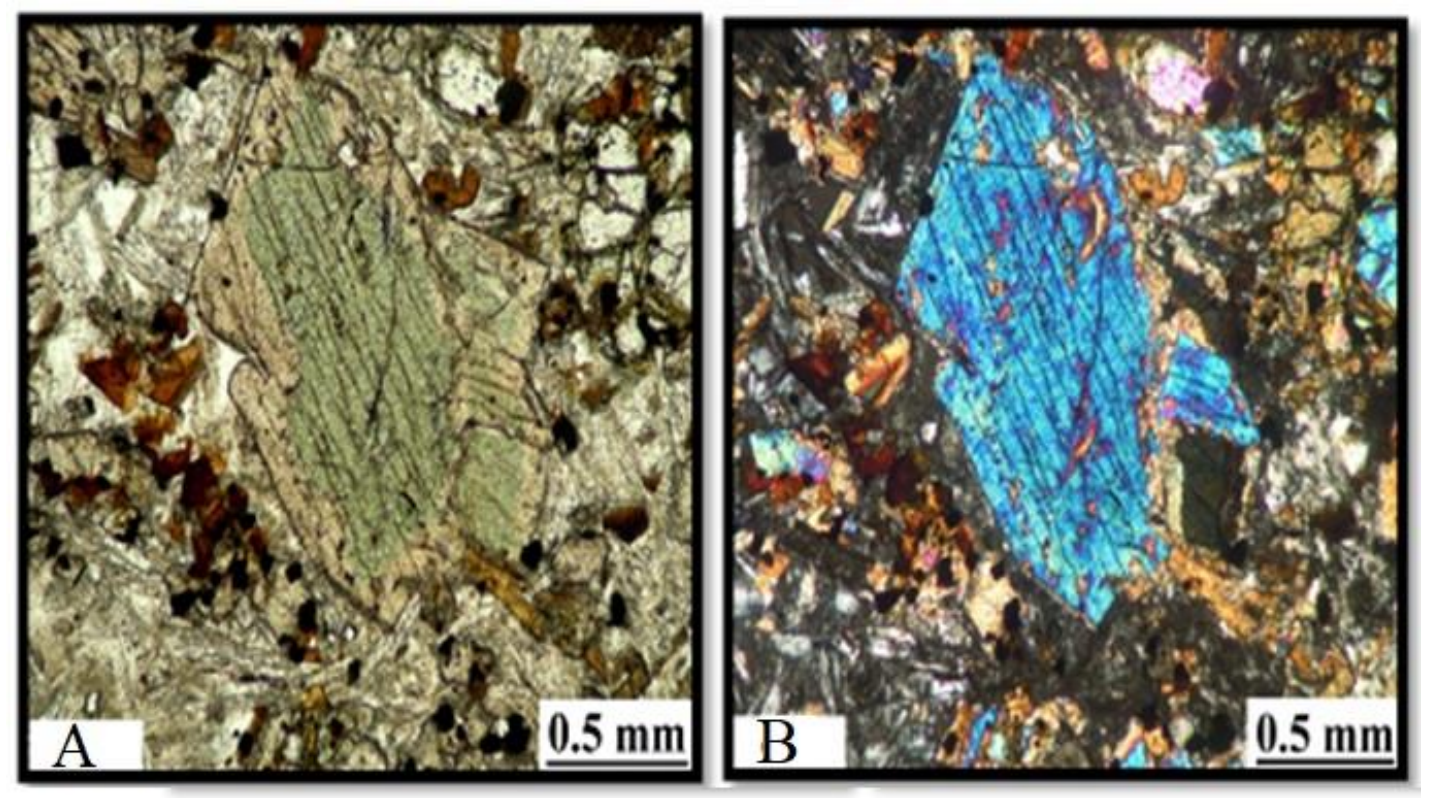

Figure 3. Clinopyroxene with green core and violate framing in lamprophyre: (A) PPL (B) XPL.

In some cases, the lime digestion was seen and later completely changed the micro structure into clinopyroxene needles. The different colors in needles is understood as the high content of Ti and $\mathrm{Na}$. The presence of carbonate xenoliths assumes crustal contamination in the rocks. (Mollo et al., 2010) states that magma-carbonate highly effective interaction associates with the formation of a residual melt, enriched in alkaline and saturated silica. Both $\mathrm{CaCo}_{3}$ dissolution in melt and the formation of diopside by consuming $\mathrm{SiO}_{2}-\mathrm{MgO}$ cause the silica declination as follow:

$$
\mathrm{CaCO}_{3} \text { Solid }+\mathrm{SiO}_{2} \stackrel{\text { Melt }}{\longrightarrow}+\mathrm{MgO} \text { Melt } \quad \text { Diopside }{ }^{\text {Solid }}+\mathrm{CO}_{2} \text { Fluid }
$$

the carbonate absorption rate is controlled by the amount of $\mathrm{MgO}$ in the melt. Xenocrystals fragments with plagioclause also may appear with sieve texture in the rocks. Their matrix formation consists of plagioclase blades, abundant biotite minerals, clinopyroxene and olivine and opaque minerals. It can be assumed the contamination of the lavas with continental crust due to the presence of carbonate and xenocrystals fragments with plagioclase. According to, based on the observation of mineralogy such as olivine mineralogical paragenesis, alkaline clinopyroxenes, nephlein, apatite, and the presence of abundant biotite , according to the of Streckeisen's (1967) modal classification these rocks consists of Alkaline lamprophyres of the camptonite type. 

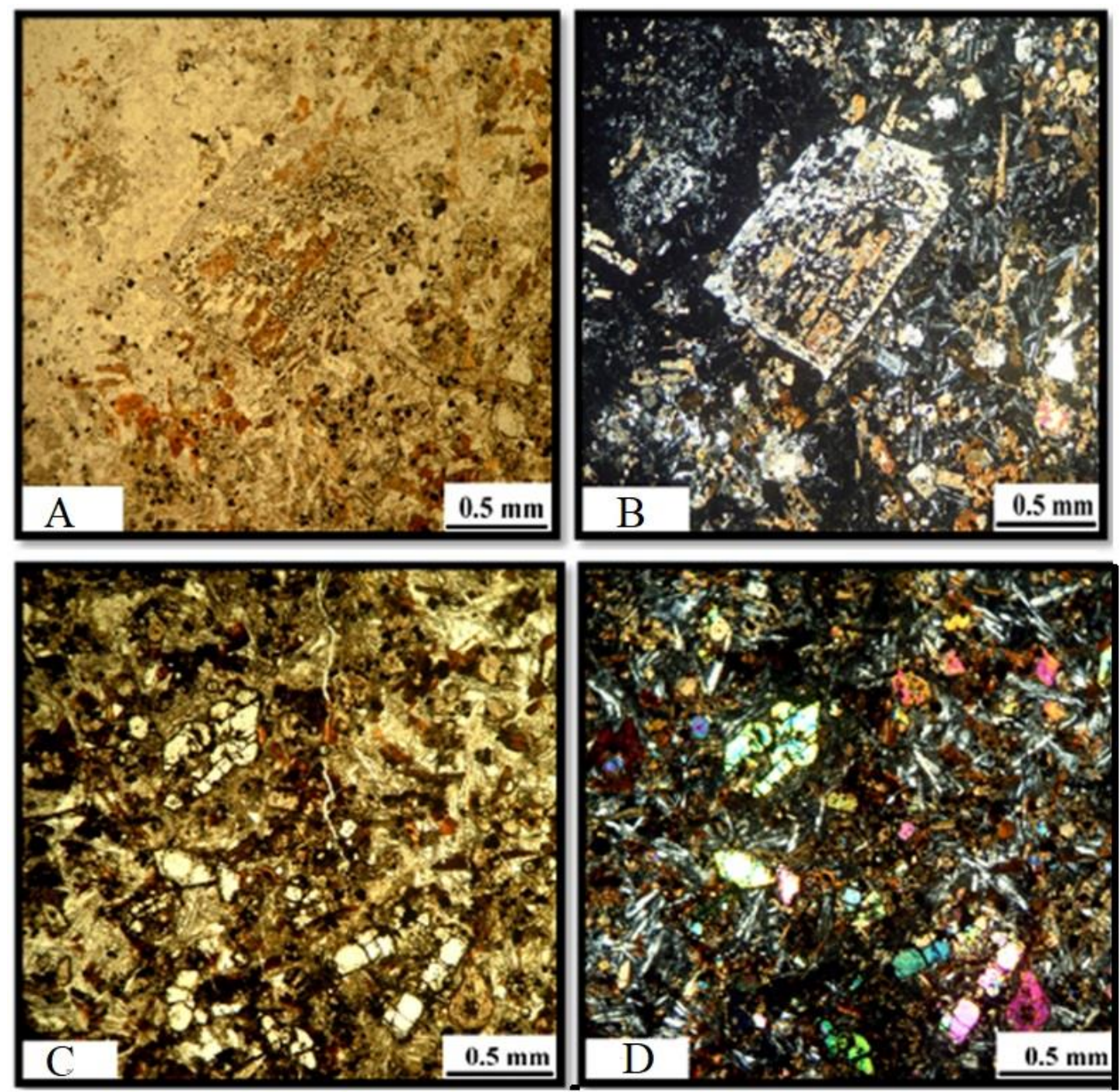

Figure 4. Alteration of phenocrysts to amphibole A: (A) PPL (B) XPL. C-Automorphic to semi-automorphic crystals of olivine in the sampled lamprophyres: (C) PPL (D) XPL.

\section{GEOCHEMISTRY}

The results of element analyses with the ICP-AES method for main elements and with the ICPMS method for secondary and rare earth elements are presented in Tables (1) respectively. The amount of $\mathrm{SiO}_{2}$ in the sampled rocks varies from $42.94 \%$ to $46.2 \%$ and averages at $45 \%$. The samples have an $\mathrm{Mg \#}$ of 55.1-58.8 and a $\mathrm{MgO}$ content of 23.8\%-53.6\%. The average amount of $\mathrm{Na}_{2} \mathrm{O}$ and $\mathrm{K}_{2} \mathrm{O}$ in the samples is $3.9 \%$ and $2.68 \%$ respectively. In the total alkali-silica plot (Cox et al., 1979), the combination of high alkali and low $\mathrm{SiO}_{2}$ content put the samples in the category of tephrite-basanite with alkaline series (Figure 5). According to the classification of Rock (1987), these rocks belong to the category of alkaline lamprophyres. The CIPW norm calculated for nepheline and olivine is $8.5 \%$ and $7 \%$, respectively. Thus, according to the classification of Yoder and Tilley (1962), the rocks classify as alkaline. In the $\mathrm{K}_{2} \mathrm{O} / \mathrm{Na}_{2} \mathrm{O}$ versus $\mathrm{SiO}_{2}$ plot (Jaques et al., 1985), all samples have $\mathrm{K}_{2} \mathrm{O} / \mathrm{Na}_{2} \mathrm{O}<1$ and are fall in the category of sodic rocks (Figure 6). According to Rock (1987), one of the characteristics of alkaline lamprophyres is $\mathrm{K}_{2} \mathrm{O} \leq \mathrm{Na}_{2} \mathrm{O}$, 
and in contrast, calc-alkaline lamprophyres have $\mathrm{K}_{2} \mathrm{O} \geq \mathrm{Na}_{2} \mathrm{O}$. The $\mathrm{K}_{2} \mathrm{O} / \mathrm{Na}_{2} \mathrm{O}<1$ observed in the sampled rocks is also a typical feature of magmatism in non-orogenic regions (Wilson, 2005). The high LOI (up to $24.5 \mathrm{wt} \%$ ) observed in the samples is consistent with the presence of hydrate minerals like biotite and is a common feature of lamprophyres (Rock, 1991; Jafari, and Yazdi 2014). The high $\mathrm{TiO}_{2}$ content $(2.8 \mathrm{wt} \%)$ is an indicator of alkalinity of these rocks (Rock.1991). Hence, based on geochemical analysis, the rocks of the region classify as sodic alkaline lamprophyres.

Table 1: Results of ICP-AES analysis for main elements.

\begin{tabular}{|c|c|c|c|c|c|c|c|c|}
\hline Sample & DB -1 & DB - 2 & DB - 5 & DB -8 & DB- 10 & DB -11 & DB - 12 & DB - 23 \\
\hline $\mathrm{SiO} 2$ & 47.255 & 47.150 & 47.044 & 47.189 & 46.921 & 47.162 & 46.976 & 45.470 \\
\hline $\mathrm{A} 12 \mathrm{O} 3$ & 15.890 & 15.371 & 15.545 & 15.627 & 15.676 & 15.858 & 15.590 & 14.714 \\
\hline $\mathrm{Fe} 2 \mathrm{O} 3$ & 4.227 & 4.237 & 4.203 & 4.137 & 4.252 & 4.253 & 4.212 & 4.173 \\
\hline $\mathrm{FeO}$ & 6.010 & 6.281 & 6.158 & 6.021 & 6.030 & 6.089 & 6.151 & 7.252 \\
\hline $\mathrm{CaO}$ & 8.776 & 9.015 & 8.867 & 8.825 & 8.804 & 8.742 & 8.941 & 11.910 \\
\hline $\mathrm{MgO}$ & 6.782 & 7.239 & 7.476 & 7.456 & 7.398 & 6.827 & 7.310 & 8.807 \\
\hline $\mathrm{K} 2 \mathrm{O}$ & 3.261 & 2.814 & 3.037 & 2.952 & 3.264 & 3.048 & 2.994 & 0.942 \\
\hline $\mathrm{Na} 2 \mathrm{O}$ & 4.154 & 4.258 & 4.091 & 4.290 & 4.080 & 4.325 & 4.233 & 3.071 \\
\hline $\mathrm{MnO}$ & 0.187 & 0.187 & 0.184 & 0.184 & 0.183 & 0.185 & 0.186 & 0.257 \\
\hline $\mathrm{TiO} 2$ & 2.669 & 2.679 & 2.669 & 2.605 & 2.641 & 2.708 & 2.664 & 2.568 \\
\hline $\mathrm{P} 2 \mathrm{O} 5$ & 0.789 & 0.769 & 0.726 & 0.715 & 0.752 & 0.803 & 0.743 & 0.835 \\
\hline $\mathrm{Total}$ & 100 & 100 & 100 & 100 & 100 & 100 & 100 & 100 \\
\hline
\end{tabular}

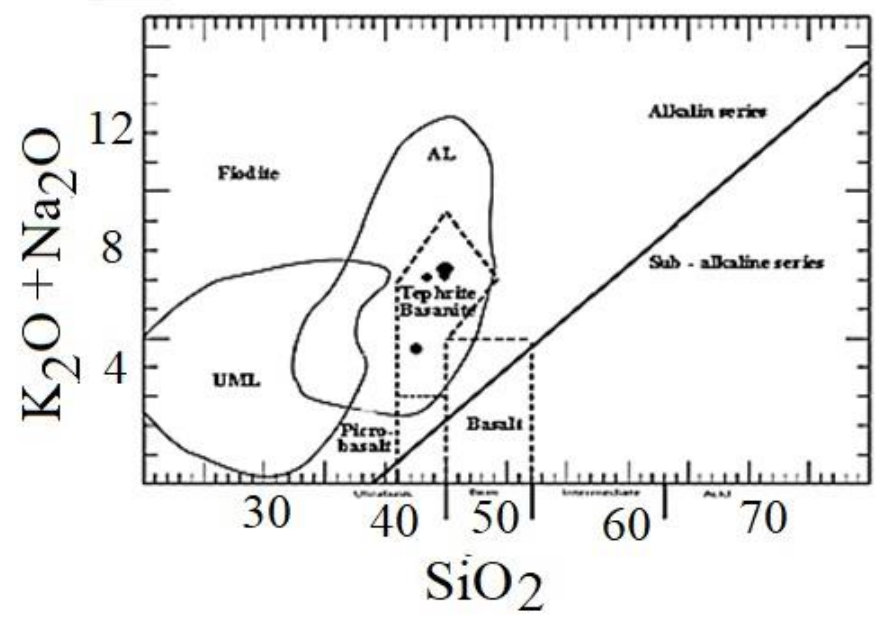

Figure 5. Position of samples in the total alkali-silica plot (Cox et al., 1979) and Rock's classification (Rock, 1987) Al:alkaline lamprophyre UMF:ultramafic lamprophyre

As shown in Figure (6-B), there is a positive linear relationship between $\mathrm{K}_{2} \mathrm{O}$ and $\mathrm{Rb}$, which suggests that weathering after the placement of magma has had little effect on the geochemistry of the rocks (Chalapathi and Dharma, 2012). The primitive mantle-normalized REE pattern of the sampled rocks (Sun and McDonough, 1989) is relatively smooth and lacks sharp spikes (Figure 
7), which is an indicator of intraplate magmatism (Wilson, 1989). There is a small positive $\mathrm{Sr}$ anomaly, but the absence of a positive Eu anomaly indicates that this cannot be caused by the accumulation of plagioclase. Given the presence of plagioclase xenocrysts, this anomaly can be attributed to crustal contamination. The small negative $\mathrm{Nb}$ anomaly observed in the samples is probably due to low levels of crustal contamination during ascent. In the Th-Hf/3-Ta ternary plot (Wood, 1980), all sample fall in the range of intraplate alkaline basalts (Figure 8-B). In the plot of $\mathrm{Ti} / \mathrm{Y}$ versus $\mathrm{Nb} / \mathrm{Y}$ (Pearce, 1982), all samples are in the range of intraplate alkali basalts (Figure 8-B). In the logarithmic plot of Th/Hf versus Ta/Hf (Wang et al., 2001), all samples are in the range of intraplate alkali rift basalts (Figure 8-C). Overall, geochemical results suggest that the rocks are alkaline lamprophyres associated with alkali basalts of intraplate rifts.

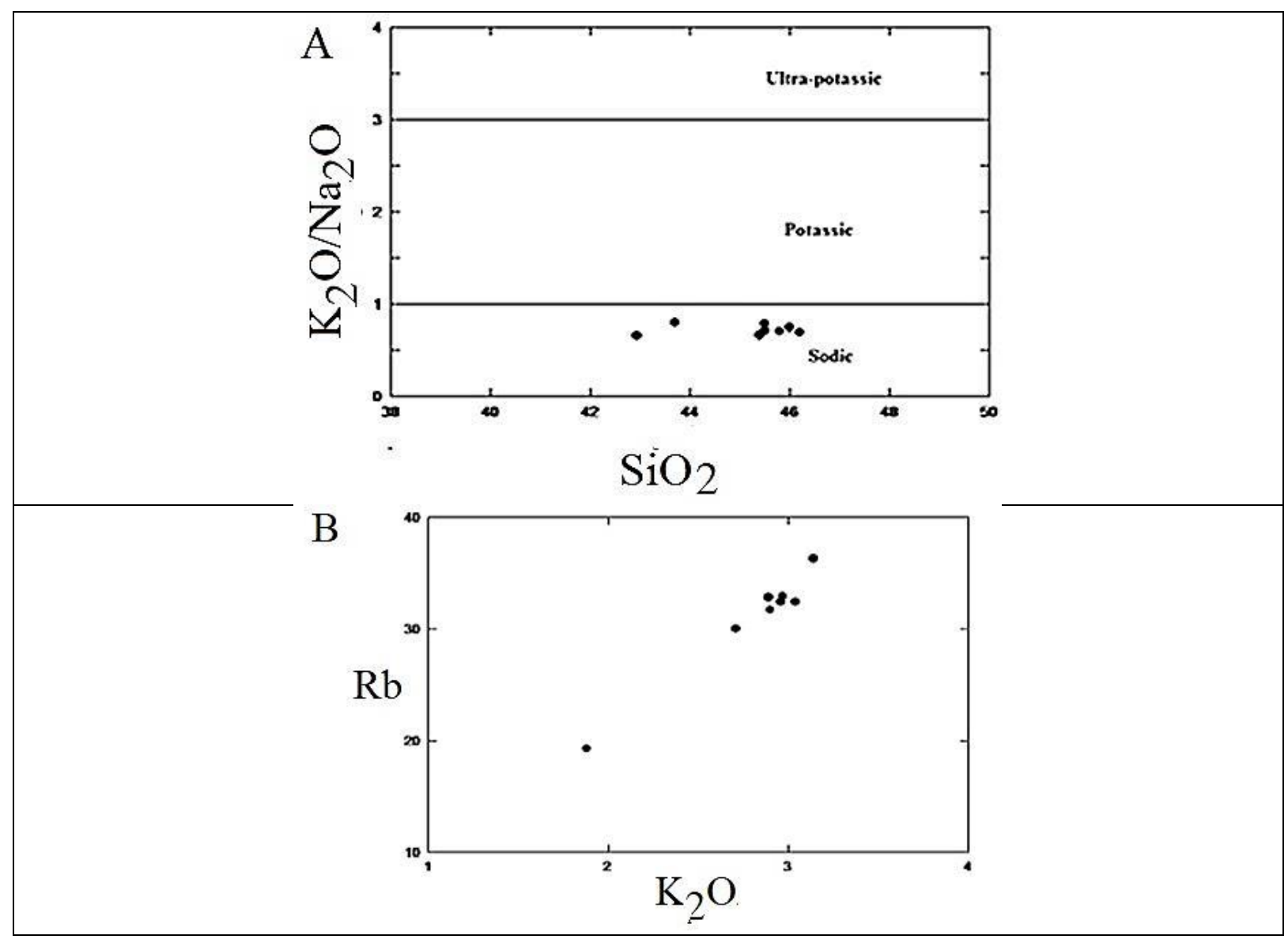

Figure 6-A-: Position of samples in the $\mathrm{K}_{2} \mathrm{O} / \mathrm{Na}_{2} \mathrm{O}$ vs. silica plot (Jaques et al., 1985). B-Position of samples in the $\mathrm{Rb}$ vs. $\mathrm{K}_{2} \mathrm{O}$ plot (Chalapathi and Dharama, 2012) 


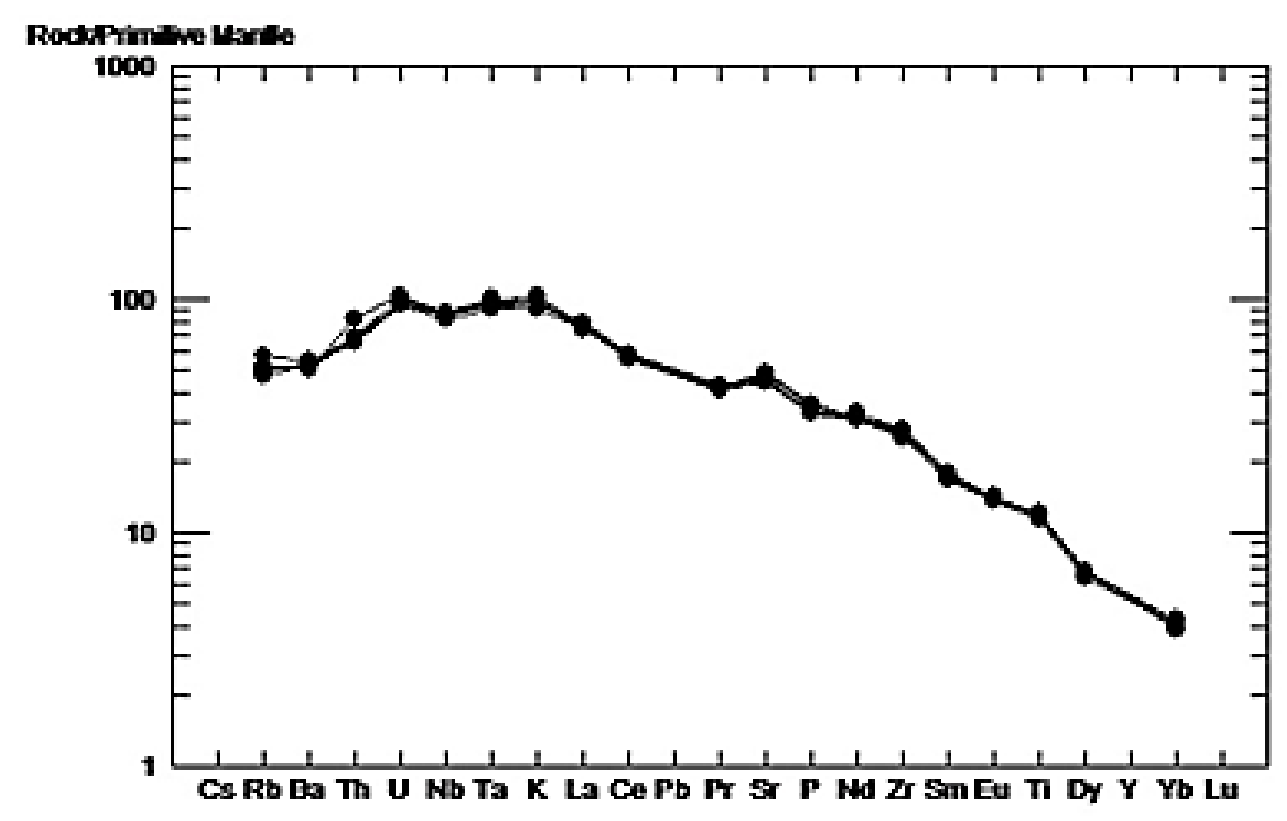

Figure 7: Primitive mantle-normalized REE pattern of the sampled lamprophyres

Table 2: Results of isotope analysis for $\mathrm{Sr}$ and $\mathrm{Nd}$ in the sampled lamprophyres.

\begin{tabular}{|c|c|c|c|}
\hline Sample & ${ }^{87} \mathrm{Sr} /{ }^{86} \mathrm{Sr}$ & ${ }^{143} \mathrm{Nd} /{ }^{144} \mathrm{Nd}$ & $\boldsymbol{\varepsilon N d}$ \\
\hline B23 & 0.704609 & 0.512779 & 2.8 \\
\hline B2 & 0.704079 & 0.512763 & 2.43 \\
\hline
\end{tabular}




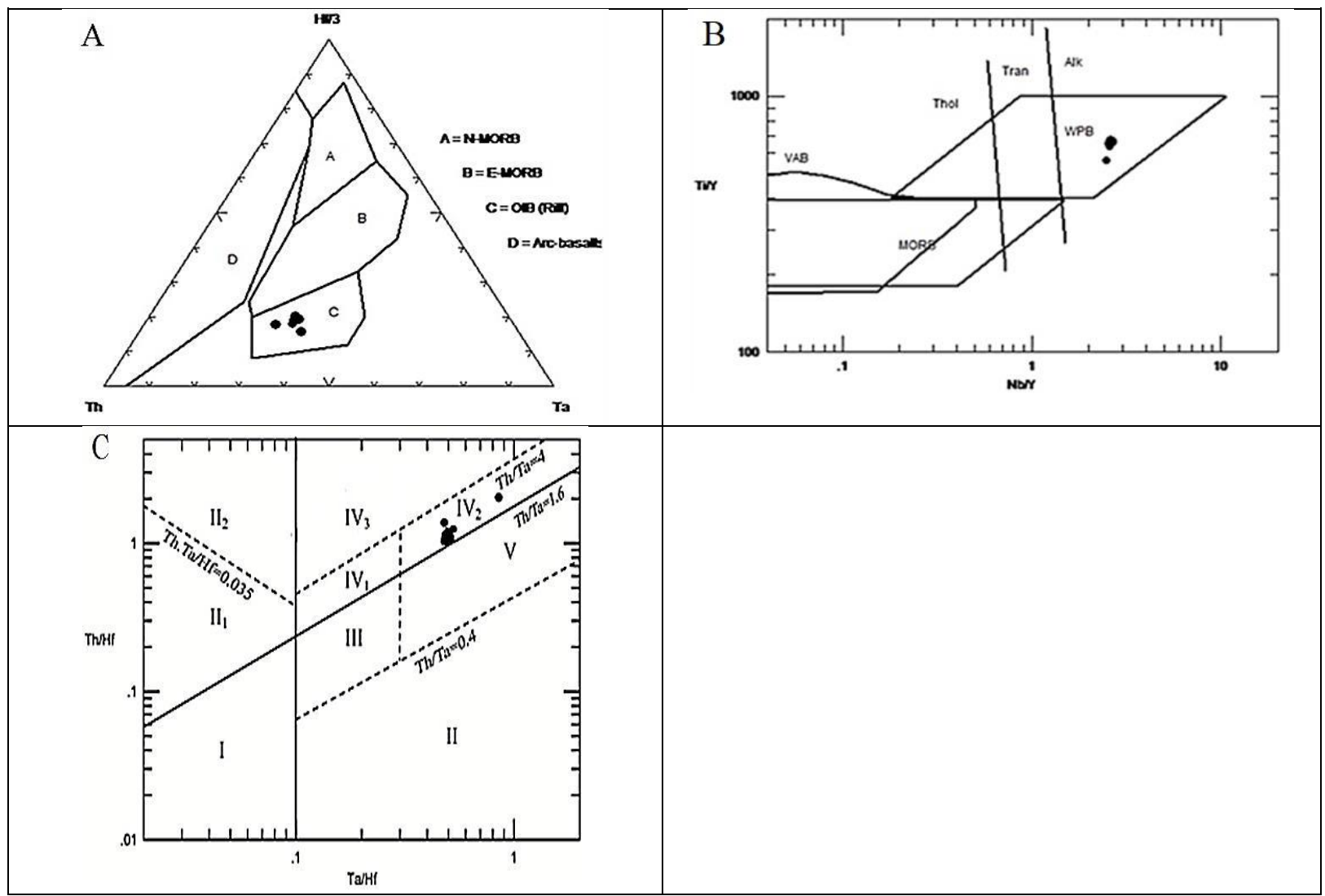

Figure 8-A- Position of samples in the Th-Hf/3-Ta ternary plot (Wood, 1980) based on immobile HFS elements. BPosition of samples in the logarithmic plot of Ti/Y vs. Nb/Y (Pearce, 1982). C-: Position of samples in the logarithmic plot of Th/Hf vs. Ta/Hf (Wang et al., 2001). The ranges have been defined as follows: I: $\quad$ N-type MORB of divergent plate margins. II: Basalts of convergent plate margins II1:Basalts of oceanic island arcs II2:Basalts of continental volcanic arc margins and continental island arc margins. III:E-type and T-type MORB and ocean island intraplate basalts IV:Continental intraplate basalts IV1:Basalts of intra-continental rifts and continental margin tholeiitic rifts IV2:Alkali basalts of intra-continental rifts IV3:Basalts of continental extensions or primary rifts. V: Mantle plume basalts.

\section{CONCLUSIONS}

All petrogenetic and geochemical evidence suggest that lamprophyric magmas are produced by low degree melting of mantle source at a depth of 100-150 kilometers (Rock, 1991). These magmas usually have high concentrations of volatile substances $\left(\mathrm{H}_{2} \mathrm{O}, \mathrm{CO}_{2}, \mathrm{~F}\right)$ and incompatible trace elements (Ba, Sr, Zr, LREE). It has been suggested that these high concentrations of volatiles originate from an incompatible/volatile element-rich mantle source (Rock, 1991) or from the metasomatism of CO2-H2O-F rich fluid (Mckenzie, 1989) (Maury et al., 1992). More recent studies have proposed different models for the genesis of lamprophyres (Chalapathi and Dharma, 2012):

1) Low degree partial melting of metasomatized continental lithospheric mantle (Rocchi et al, 2009) (Scarrow et al, 2009) (Owens and Tomascak, 2002)

2) Extreme differentiation of a volatile-rich basic magma (Currie and Williams, 1993) 
3) Asthenospheric magmas differentiated from mantle plume (Kerr et al., 2010)

4) Mixing of ultrabasic magma with crustal materials (McDonald et al., 1985)

5) Mixing of basic and alkaline magmas (Zhang et al., 2007).

The molten rock that arrives at the surface in lava form provides valuable insights into the geochemistry of the mantle (Hofmann, 1997). Geochemists can use chemical tracers to identify mantle sources. Typically, these tracers are either the ratio of radioactive isotopes or the ratio of incompatible trace elements (Hofmann 1997). The La/Ta ratio can be used to determine the lithospheric or asthenospheric origins of basaltic magmas (Fitton et al., 1988). More specifically, $\mathrm{La} / \mathrm{Ta}<22$ indicates a lithospheric origin and $\mathrm{La} / \mathrm{Ta}>30$ is an indicator of subcontinental lithospheric mantle origin. In the area surveyed in this study, this ratio was 13.2, indicating the asthenospheric origin of the studied lamprophyres. For the lamprophyres of the region, the $\mathrm{La} / \mathrm{Ta}$ ratio is about 0.8 , which reflects the asthenospheric origin of these rocks (Thompson et al., 1984). In the plot of $\mathrm{Nb} / \mathrm{La}$ versus $\mathrm{La} / \mathrm{Yb}$ (Abdel-Rahman, 2002), all samples fall in the range of asthenospheric mantle and near the range of ocean island basalt (OIB) (Figure 9-A).

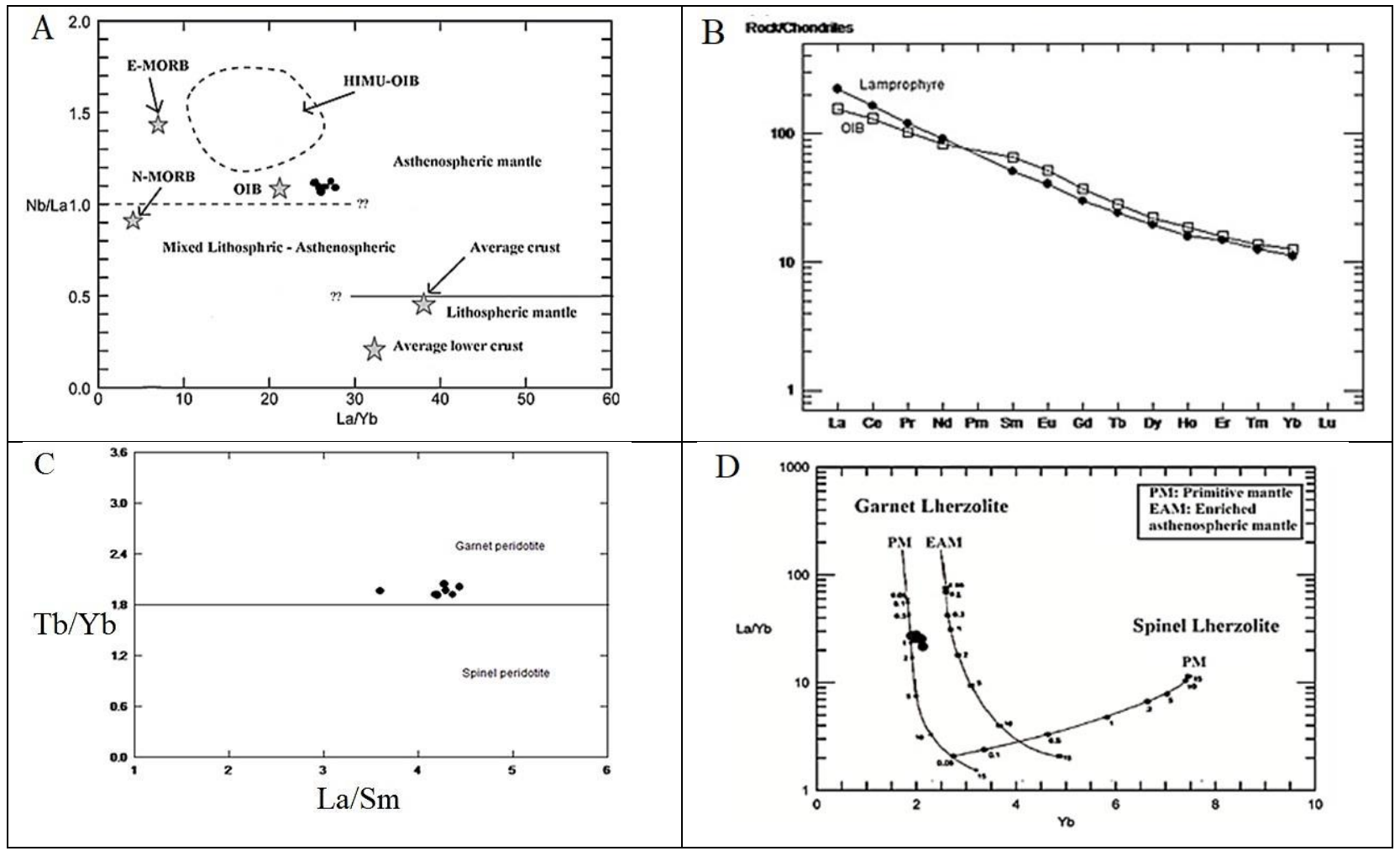

Figure 9-A: Position of the samples in the plot of Nb/La vs. La/Yb (Abdel-Rahman, 2002). B-Comparison of mean concentration of elements in the sampled lamprophyres with the corresponding values in OIB (Sun and McDonough, 1989). C-Position of the samples in the plot of (Tb/Yb)N vs. (La/Sm)N (Wang et al., 2002). D -Position of the samples in the plot of $\mathrm{La} / \mathrm{Yb}$ vs. Yb (Nedli and Toth, 2007)

The REE pattern of the region's lamprophyres is identical to that of OIB (Figure 9-B). According to Thompson (1985), lamprophyres with OIB-like REE patterns originate from the asthenospheric mantle. As shown in Figure 18, which illustrates the plot of $(\mathrm{Tb} / \mathrm{Yb}) \mathrm{N}$ versus $(\mathrm{La} / \mathrm{Sm})$, all samples have a $(\mathrm{Ta} / \mathrm{Yb}) \mathrm{N}$ ratio of more than 1.8 , which reflects their lherzolite garnet origins (Wang et al. 2002). Experimental petrological studies have shown that 
alkaline rocks can be produced from low-degree partial melting of a lherzolite garnet source (Green, 1973). Figure (10-D) displays the semi-logarithmic plot of La/Yb versus Yb (Nedli and Toth, 2007). As can be seen, all samples are in the range of $1 \%$ melting of a non-enriched lherzolite garnet source. The results of $\mathrm{Nd}-\mathrm{Sr}$ isotopic correlation analysis of two samples are presented in Table (2). In Figure (10-D), the Nd-Sr isotopic correlation plot of these samples shows their position in the range of OIB mantle.

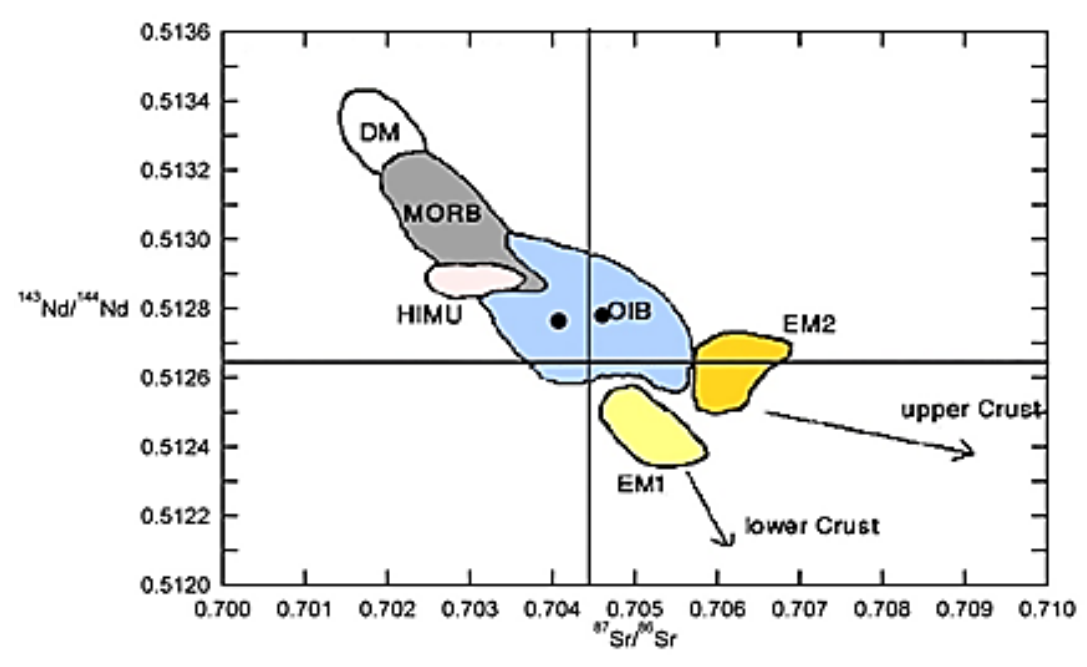

Figure 10: Position of the samples in the Nd-Sr isotopic correlation plot (Rollinson, 1993)

The positive $\varepsilon \mathrm{Nd}$ value of the samples signify the genesis of magmas from a non-enriched OIB mantle source (Rollinson, 1993). In Figure 10, where $\varepsilon$ Nd is plotted versus ${ }^{87} \mathrm{Sr} /{ }^{86} \mathrm{Sr}$ (Leterrier, 1985), it can be seen that the samples are in the second quarter in the joint range of continental basalts and mantle plume OIB. Geochemical and petrographic analyses of the sampled rocks indicate that they are alkaline lamprophyres with an OIB-like non-enriched asthenospheric origin involving partial (1\%) melting of an intact (non-enriched) lherzolite garnet source in an intracontinental rift zone.

\section{REFERENCES}

Abdel - Rahman, A. M. (2002). Mesozoic volcanism in the Middle East: geochemical, isotopic and petrogenetic evolution of extensionrelated alkali basalts from central Lebanon, Geological Magazine 139, $621-640$.

Agard, P., Omrani, J., Jolivet, L., Whitechurch, H., Vrielynck, B. (2011). Zagros orogeny: a subductiondominated process, Geological Magazine, 148, 692-725.

Baratian, M., Arian, M.A., Yazdi, A. (2020). Petrology and Petrogenesis of Siah Kooh Volcanic Rocks in the Eastern Alborz. Geosaberes, 11, 349-363

Bazoobandi, M.H., Arian, M.A., Emami, M.H., Tajbakhsh, G., Yazdi, A. (2016). Petrology and Geochemistry of Dikes in the North of Saveh in Iran, Open journal of marine science, 6(02), 210-222.

Behzadzadeh, H. (1999). Petrology of Tertiary intrusive masses east of Lushan, Master Thesis, Shahid 
Beheshti University.

Chalapathi Rao, N.V., Dharma Rao, C.V., Sanjay, D. (2012). Petrogenesis of lamprophyres from Chhota Udepur area, Narmada rift zone, and its relation to Deccan magmatism, Journal of Asian Earth Sciences, 45, 24-39.

Cox, K.G., Bell, J. D., Pankhurst, R. J. (1979). The interpretation of igneous rocks, George Allen and unwin, London, 450.

Currie , K.L., Williams, P.R. (1993). An Archean calc-alkaline lamprophyre suite, northeastern Yilgarn Block, western Australia, Lithos 31, 33-50.

Emami, M. H. (1981). Geologe de la regione de Qom - Aran (Iran), These es sciences naturelles Univ. Sc. et Medicale de Grenoble, France, 489.

Engalence, M. (1968). Géologe, géomorphologie, hydrogeology de la region de Téhran, Thése es sciences, Monpellier, 180.

Fazl Nia, A., Koozeh Kalani, F. (2012). Petrography, Geochemistry and Tectonomagmatic Environment of Lamprofires and Related Stones, Southwest Salmas, Petrology, 3, 12

Fitton, J.G., James, D., Kempton, P.D., Ormerod, D.S., Leeman, W.P. (1988). The role of lithospheric mantle in the generation of Late Cenozoic basic magma in the western United States, Journal of Petrolgy, 331-349.

Ghalamgash, J. (2002). Geological map of Jirnde 1.1000, Geological Survey of Iran.

Green, D. H. (1973). Conditions of melting of basanite magma from garnet peridotite, Earth Planet Sci. Lett.17,456-465.

Hofmann, A.W. (1997). Mantle geochemistry: the message from oceanic volcanism, Nature, 385, 219229.

Ismaili, L. (2010). Petrology of intrusive masses of four places in the east of Rudbar, Master Thesis, Islamic Azad University, Lahijan Branch.

Jafari, H.R., Yazdi, A. (2014). Radioactive Anomalies in 1: 50000 Dehbakri Sheet, South of Kerman Province, Iran, Open Journal of Geology, 04(08),399-405, DOI:10.4236/ojg.2014.48031

Jaques, A.L., Creaser, R.A., Ferguson J., Smith C.B. (1985). A review of the alkaline rocks of Australia, Trans. Geol. Soc. S. Afr. 88,311-334.

Kerr, A.C., Khan M., Mahoney J.J., Nicholson K.N., Hall C.M. (2010). Late Cretaceous alkaline sills of the south Tethyan suture zone, Pakistan: initial melts of the Réunion hotspot?, Lithos, 117,161-171.

Leterrier, J. (1985). Mineralogical, geochemical and isotopic evolution of tow Miocene mafic intrusions from the Zagros (Iran), Lithos, 18,311 - 329.

Maury, R.C., Define, M.G., Goron, G.L. (1992). Methasomation of the sub - Arc mantle inferred from trace element in Philipines, Xenolith nature, 360, $661-663$.

McDonald, R., Thorpe, R.S., Gaskarth, J.W. (1985). Multi-source origin for lamprophyres of North 
England, Mineralogical Magazine, 49, 485-494.

McKenzie, D.P. (1989). Some remark on the movement of small melt fraction in the mantle, Earth and planetray science letter, 95, $53-72$.

Moin Vaziri, H., Ahmadi, A. (2008). Petrography and petrology of igneous rocks, Tarbiat Moallem University.

Mollo, S., Del Gaudio, P., Ventura, G., Iezzi, G., Scarlato, P. (2010a). Dependence of clinopyroxene composition on cooling rate in basaltic magmas: Implications for thermobarometry, Lithos, 118, 302- 312, doi:10.1016/j.lithos.2010.05.006.

Mollo, S., Gaeta, M., Freda, C., Di Rocco, T., Misiti, V., Scarlato. P. (2010b). Carbonate assimilation in magmas: A reappraisal based on experimental petrology, Lithos, 114, 503-514.

Nédli, Zs., Toth, T. M. (2007). Origin and geodynamic significance of Upper Cretaceous lamprophyres from the Villány Mts (Hungary), Mineralogy and Petrology, 90, 73-107.

Owens, B.E., Tomascak, P.B. (2002). Mesoproterozoic lamprophyres in the Labrievell Massif, Quebec: clues to the origin of alkalic anorthosites?, Canadian Journal of Earth Sciences, 39, 983-997.

Pearce, J.A. (1982). Trace element characteristics of lavas from destructive plate boundaries, In: Thorpe R.S. (ed) Andesites, Wiley, Chichester, 525-548.

Poorbehzadi, K., Yazdi, A., Sharifi Teshnizi, E., Dabiri, R. (2019). Investigating of Geotechnical Parameters of Alluvial Foundation in Zaram-Rud Dam Site, North Iran. International Journal of Mining Engineering and Technology, 1(1), 33-34

Rocchi, S., Vincenzo, G. D., Ghezzo, C., Nardini, I. (2009). Granite-lamprophyre connection in the latest stages of the early Paleozoic Ross Orogeny (Victoria Land, Antarctica), Bulletin of Geological Society of America, 121,801-819.

Rock, N.M.S. (1987). The nature and origin of lamprophyres: an overview, In: Fitton J.G. Upton B.G.J. (eds) Alkaline igneous rocks, Geol. Soc. Lond. Spec. Publ. 30,191-226.

Rock, N.M.S. (1991). Lamprophyres, Blackie and Sons Ltd, Glasgow, 285.

Rollinson, H.R. (1993).Using Geochemical Data: Evaluation, Presentation, Interpretation, Longman, 370.

Scarrow, J.H., Bea, F., Montero, P., Molina, J.F. (2009). Shoshonites, Vaugnerites and potassic lamprophyres, similarities and differences between "ultra"-high-Krocks, Transactions of the Royal Society of Edinburgh, 99,159-175.

Shafei, Z. (2012). Petrography and geochemistry of volcanic rocks in Nash region located in the east of Rudbar (Gilan province), Master Thesis, Islamic Azad University, Lahijan Branch.

Stocklin, J. (1974). Iran central, septenterionat et oriental, Lexique stratigraphique International III, Fasicule 9b, Iran. 1 - center national de la Recherche scientifique, Paris

Streckisen, A. L. (1980). Classification and nomenclature of volcanic rocks, lamprophyres, carbonates and melilitics rocks, I.U.G.S. Subcommision on the systematic of Igneous Rocks, Geol. Rundsch, 69,194 $-207$. 
Sun, S.S., McDonough W.F. (1989). Chemical and isotopic systematics of ocean basalts: implications for mantle composition and process, Geol. Soc. Spec. Publ. 42, 313-346.

Taki, S. (2008). Petrology of igneous rocks of Deilman region located in Central Alborz, PhD thesis, Islamic Azad University, Research Sciences Branch.

Thompson, R. N., Morrison M. A., Hendry G. L., Parry S. J. (1984). An assessment of the relative roles of crust and mantle in magma genesis: an elemental approach, Phil. Trans R. Soc. Lond. Ser. 310, 54990.

Thompson, R.N. (1985). Asthenospheric source of Ugandan ultrapotassic magma?, Journal of Geology, $93,603-608$.

Wang, K., Plank, T., Walker, J.D., Smith, E.I. (2002). A mantle melting profile across the basin and range, SWUSA, Journal of Geophysical Research-Solid Earth, 107.

Wang, Y., Zhang, C., Xiu, S. (2001). Th/Hf - Ta/Hf discrimination diagram of geotectonic settings of basalta (J), Acta Petrologica Sinica, 17, 413 - 421 (in Chinese with English abstract).

Willson, M. H. (2005). Tertiary - Quaternary intra - plate magmatism Europe, and its relationship to mantle dynamics, Geological society of London, 32, 147-166.

Wilson, M. (1989). Igneous petrogenesis-A global tectonic approach, Unwin Hyman London, 466.

Wood, D.A. (1980). The application of a Th - Hf - Ta diagram to problems of tectonomagmatic classification and a establishing the nature of crustal contamination of basaltic lavas of the British Tertiary volcanic province, Earth Planet. Sci. Lett, 50, 11-30.

Yazdi, A., Ashja-Ardalan, A., Emami, M.H., Dabiri, R., Foudazi, M. (2019-a). Magmatic interactions as recorded in plagioclase phenocrysts of quaternary volcanics in SE Bam (SE Iran), Iranian Journal of Earth Sciences, 11(3), 215-224. DOI: http://ijes.mshdiau.ac.ir/article_667379.html

Yazdi, A., Shahhosini, E., Dabiri, R., Abedzadeh, H. (2019-b). Magmatic differentiation evidences and source characteristics using mineral chemistry in the Torud intrusion (Northern Iran). Revista Geoaraguaia, 9(2), 1-21

Yazdi, A., Sharifi Teshnizi, E. (2021). Effects of contamination with gasoline on engineering properties of fine-grained silty soils with an emphasis on the duration of exposure, Springer, SN Applied Sciences, 3, 704. doi: https://doi.org/10.1007/s42452-021-04637-x

Yoder, H,S., Tilley,C.E. (1962). Origin of basalt magmas: an experimental study of natural and synthetic rock systems .J. Petrology, 3, 342-532.

Zhang, Z. J., and Y. H. Wang. (2007). Crustal structureand contact relationship revealed from deep seismicsounding data in south China, Phys. Earth Planet. Inter, 165, 114-126, doi:10.1016/j.pepi.2007.08.005. 